\title{
Evaluation of Green Manure Amendments for the Management of Fusarium Basal Rot (Fusarium oxysporum f.sp. cepae) on Shallot
}

\author{
Assefa Sintayehu, ${ }^{1}$ Seid Ahmed, ${ }^{2}$ Chemeda Fininsa, ${ }^{3}$ and P. K. Sakhuja ${ }^{3}$ \\ ${ }^{1}$ Department of Plant Sciences, Faculty of Agriculture, Gondar University, P.O. Box 196, Gondar, Ethiopia \\ ${ }^{2}$ International Centre of Agricultural Research in Dry Areas, P.O. Box 5689, Addis Ababa, Ethiopia \\ ${ }^{3}$ School of Plant Sciences, Haramaya University, P.O. Box 138, Dire Dawa, Ethiopia \\ Correspondence should be addressed to Assefa Sintayehu; kassaassefa@gmail.com
}

Received 29 June 2013; Revised 10 December 2013; Accepted 10 December 2013; Published 4 March 2014

Academic Editor: Manuel Tejada

Copyright (C) 2014 Assefa Sintayehu et al. This is an open access article distributed under the Creative Commons Attribution License, which permits unrestricted use, distribution, and reproduction in any medium, provided the original work is properly cited.

\begin{abstract}
Shallot (Allium cepa L. var. ascalonicum) is the most traditional vegetable crop in Ethiopia. Shallot is susceptible to a number of diseases that reduce yield and quality, among which fusarium basal rot (FBR) caused by Fusarium oxysporum f.sp. cepae (Foc) is one of the most important yield limiting factors in Ethiopia. The present study was designed to evaluate the effectiveness of Brassica crops for the management of shallot FBR on shallot. The experiments were carried out at Debre Zeit Agricultural Research Center using cabbage (Brassica oleracea), garden cress (Lepidium sativum), Ethiopia mustard (B. carinata), and rapeseed (B. napus). The evaluations were done under in vitro and greenhouse conditions. Under in vitro test condition it was confirmed that extracts of Ethiopian mustard and rapeseed showed higher inhibition on the growth of Foc pathogen compared to control. Data on seedling emergence, plant height, plant stand, disease incidence, severity, cull bulbs, and bulb weight were collected in greenhouse experiment. The green manure amendments of rapeseed and Ethiopian mustard significantly reduced disease incidence by $21 \%$ and $30 \%$ and disease severity by $23 \%$ and $29 \%$, respectively. However the plant emergency was not significantly different among treatments in greenhouse test. These results indicated that Ethiopian mustard and rapeseed crops have potential as green manure for the management of FBR disease of shallot crop.
\end{abstract}

\section{Introduction}

Fusarium basal rot (FBR) of shallot caused by Fusarium oxysporum f.sp. cepae (Snyder and Hans) is an economically important disease of shallot (Allium cepa var. ascolonicum Baker) and other Allium spp. in the major growing areas of the world [1-3]. It is widely distributed in areas where environmental conditions are conducive for disease development. In Ethiopia, high yield and quality losses due to FBR on shallot occur where the crop is frequently planted without proper crop rotations $[4,5]$. The pathogen (F. oxysporum f.sp. cepae) invades plants through roots and the basal stem plate via the soil. Management of FBR can be made through fungicides but sometimes it is not practical for small-scale farmers; in this case integrated or sustainable disease control options are more desirable. Biological control has been also suggested as a possible control method for FBR [3].

Biofumigation is the agronomic practice of using volatile chemicals (allelochemicals), released from decomposing Brassica tissues, to suppress soil-borne pests through incorporation of Brassicaceae plants as green manure. It is an environmental friendly alternative to chemical control measure. The major crops in the Brassicaceae family used in biofumigation are broccoli, cauliflower, turnip, canola, rapeseed, cabbage, kale, radish, and various mustards that produce sulfur compounds called glucosinolates (GSLs) that break down to produce isothiocyanates which are toxic soil-borne pathogens [6]. Biocidal compounds of Brassica spp. released the hydrolysis of GSLs content and are used for suppression of soil-borne pests during decomposition of green manures 
or crop rotation [7-12]. Other studies have also indicated that volatile compounds released from Brassica plant material have been shown to inhibit different soil-borne pathogens, including $F$. oxysporum $[13,14]$. Inhibition of potential compounds released from certain Brassica cultivars on $F$. sambucinum and Verticillium dahliae [15] has also been demonstrated. However, GSLs concentrations vary among cultivars within Brassica spp.; mustards usually have higher toxic chemicals and are also affected by environmental conditions and plant development $[9,16,17]$. Both water soluble and volatile GSLs degradation products may, therefore, be involved in disease suppression and may be useful in the biological control of plant pathogens.

In Ethiopia different types of Brassica spp. for food and edible oils are produced in rotations with cereal crops. The objective of this study was to determine the potential effects of Brassica crops on FBR affecting shallot in Ethiopia.

\section{Materials and Methods}

2.1. In Vitro Pathogen Inhibition Assays. Fusarium oxysporum f.sp. cepae (Foc) isolate was collected from shallot bulbs of naturally infested fields of Debre Zeit Agricultural Research Center (DZARC) in Ethiopia. Foc isolate was obtained after the small samples of shallot infected tissues were surfacesterilized in $10 \%$ sodium hypochlorite $(\mathrm{NaOCl})$ for $5 \mathrm{~min}$, rinsed in sterile distilled water and placed on Petri dishes containing the growth medium potato dextrose agar (PDA), and grown at $25^{\circ} \mathrm{C}$ in incubator for 7 days prior to use in in vitro inhibition assays. The Foc pathogenicity was tested under in vitro bioassay by onion slices method [18].

Brassica crops representing potential glucosinolate levels were selected, cabbage (Brassica oleracea), Ethiopia mustard (B. carinata), rape seed (B. napus), and garden cress (Lepidium sativum). Green manure amendment seeds were planted in pots with diameter $25 \mathrm{~cm}$ and $18 \mathrm{~cm}$ depth of size for each crop, grown for 50 days in the greenhouse. After washing fresh collected leaves ( $25 \mathrm{~g}$ ) in running tap water, leaves were surface-sterilized by dipping them in $1 \%$ sodium hypochlorite $(\mathrm{NaOCl})$ for $1 \mathrm{~min}$ followed by three washes in sterile distilled water and dried on absorbent paper. The coarsely chopped leaves were thoroughly macerated with a mortar and pestle. An amount of $0.20 \mathrm{~mL}$ plant macerated material was poured into PDA Petri dishes ( $9 \mathrm{~cm}$ diameter). One agar plug $(5 \mathrm{~mm}$ diameter) was taken from the periphery of 7-day-old culture of Foc fungus and transferred to the center of macerated poured plate. The plates were immediately sealed with Para film and followed by laboratory tape; the cultures were maintained in an incubator with a temperature at $25^{\circ} \mathrm{C}$. Radial growth of the Foc pathogen was measured at 24, 48, and $72 \mathrm{~h}$ after incubation periods. Percent inhibition was determined using the following formula control - treatment/control $* 100$ [19]. The experiments were conducted twice with randomized complete block designing five replications.

2.2. Inoculum and Soil Preparations. Similar Foc isolate was used for in vitro and pot experiment. The production of inoculum was done following the methods of Lacy and
Robert [18]. Pathogen Foc was grown on autoclaved wheat grains for artificial soil infestation. Wheat grain (250 g) was placed in $100 \mathrm{~mL}$ of distilled water and autoclaved. After the grain was cooled, it was inoculated with 5 plugs of $5 \mathrm{~mm}$ disk of actively grown Foc and incubated at $24^{\circ} \mathrm{C}$ for two weeks. Flasks were shaken by hand daily (10 sec each). After incubation, the colonized wheat seeds were air-dried and stored in a refrigerator at $4^{\circ} \mathrm{C}$ until further uses. Four $\mathrm{kg}$ of sterilized soil was filled in $25 \mathrm{~cm}$ diameter pots. Foc inoculum was incorporated with the sterilized soil at a rate of $10 \mathrm{~g} \mathrm{~kg}^{-1}$ and allowed to equilibrate for $24 \mathrm{~h}$ prior to planting shallot.

2.3. Greenhouse Pot Experiment. Similar crops were used in the in vitro inhibition tests and in the greenhouse experiment. The pot experiment of green manure amendments was conducted in green house. Each pot was filled with four kg of sterilized soil infested with Foc. The biofumigant crops used in this study were cabbage (Brassica oleracae), garden cress (Lepidium sativum), Ethiopia mustard (B. carinata), and rape seed (B. napus). Foc infested pots planted without green manure amendment were used as controls. Foc noninfested soil pot was also used as another control treatment.

Seeds were planted in sterilized infested soil pot for 50 days, crop biomass from each treatment was uprooted and chopped into $2 \mathrm{~cm}$ pieces, and finally these pieces incorporated directly into the same pot at the rate of $75 \mathrm{~g} / \mathrm{kg}$ of soil. The pots were covered by plastic for two weeks to prevent loss of biofumigants [20]. After incorporation of the chopped plants, the green manure was allowed to decompose in the soil for 45 days. Treatments were arranged in a randomized complete block design with five replications. Four bulbs of susceptible type local shallot cultivars (Fedis) were planted in each pot.

2.4. Data Collections and Analyses. After planting, data on plant emergence, plant height, final plant stand, disease incidence, and severity were collected from the experiments. All shallot bulbs were hand-harvested from each pot and were separated into cull bulbs due to FBR disease and weighed after 10 days of curing. Bulbs were washed, graded, and rated for incidence of cull bulbs (where disease symptoms adversely affect marketability) and severity of diseased bulbs [21].

The incidence of FBR in each pot was recorded on the basis of foliar symptoms (such as chlorosis which leads to tip necrosis and plant death) at 15-day intervals from the first appearance of the disease. At harvest time per plant severity of FBR was recorded on a 1-5 scale, where 1 means without any decay symptom, 2 means up to $10 \%$ rotted roots, 3 means $10-$ $30 \%$ rotted roots with up to $10 \%$ rotted basal plates, 4 means completely rotted roots and $10-30 \%$ rotted basal plates, and 5 means completely rotted roots and more than 30\% rotted basal plates [22]. FBR severity scores were converted into percentage severity index (PSI):

$$
\text { PSI }=\frac{\text { Sum of numerical ratings } \times 100}{\text { No. of plants scored } \times \text { Maximum score on scale }} \text {. }
$$


TABLE 1: Effect of green manure crops on fusarium basal rot disease parameters and agronomic traits of shallot.

\begin{tabular}{|c|c|c|c|c|c|c|c|}
\hline Treatments & $\begin{array}{c}\text { Incidence } \\
(\%)\end{array}$ & $\begin{array}{c}\text { Severity } \\
(\%)\end{array}$ & $\begin{array}{c}\text { Cull bulb } \\
(\%)\end{array}$ & $\begin{array}{c}\text { Plant emergency } \\
(\%)\end{array}$ & $\begin{array}{c}\text { Final stand count } \\
(\%)\end{array}$ & $\begin{array}{l}\text { Plant height } \\
(\mathrm{cm})\end{array}$ & $\begin{array}{c}\text { Bulb weight } \\
\text { (g/pot) }\end{array}$ \\
\hline Cabbage & $28.44^{\mathrm{ab}}$ & $23.40^{\mathrm{abc}}$ & $5.27^{\mathrm{abc}}$ & $95.00^{\mathrm{ns}}$ & $75.00^{\mathrm{bc}}$ & $31.83^{\mathrm{b}}$ & $115.60^{\mathrm{bc}}$ \\
\hline Garden cress & $26.62^{\mathrm{ab}}$ & $24.90^{\mathrm{ab}}$ & $5.39^{\mathrm{ab}}$ & 90.00 & $85.00^{\mathrm{abc}}$ & $34.52^{\mathrm{ab}}$ & $122.10^{\mathrm{abc}}$ \\
\hline Rapeseed & $24.11^{b c}$ & $20.30^{\mathrm{bc}}$ & $3.97^{\mathrm{c}}$ & 90.00 & $85.00^{\mathrm{abc}}$ & $35.99^{\mathrm{a}}$ & $147.20^{\mathrm{ab}}$ \\
\hline Ethiopian mustard & $21.54^{\mathrm{c}}$ & $18.70^{\mathrm{c}}$ & $4.75^{\mathrm{bc}}$ & 95.00 & $90.00^{\mathrm{ab}}$ & $36.01^{\mathrm{a}}$ & $145.80^{\mathrm{ab}}$ \\
\hline Control with pathogen & $30.67^{\mathrm{a}}$ & $26.50^{\mathrm{a}}$ & $6.16^{\mathrm{a}}$ & 95.00 & $70.00^{c}$ & $34.21^{\mathrm{ab}}$ & $105.30^{\mathrm{c}}$ \\
\hline Control without pathogen & 0.00 & 0.00 & 0.00 & 100.00 & $95.00^{\mathrm{a}}$ & $36.21^{\mathrm{a}}$ & $156.10^{\mathrm{a}}$ \\
\hline LSD $(0.05 \%)$ & 4.85 & 5.55 & 1.39 & ns & 17.87 & 4.09 & 39.15 \\
\hline
\end{tabular}

Means are combined average values for two experiments.

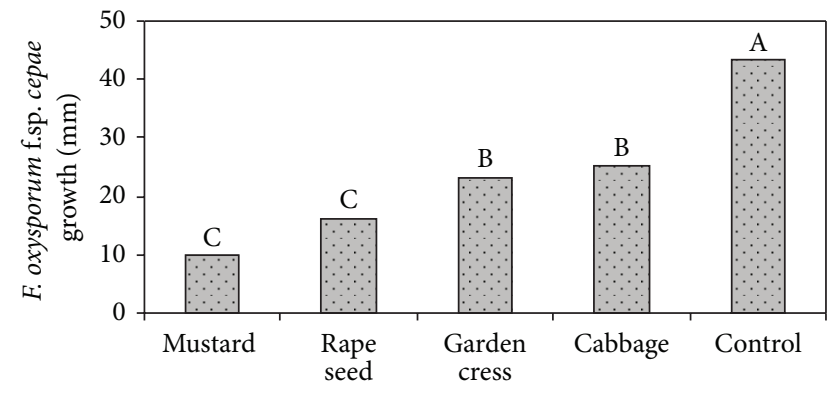

Figure 1: Effect of macerated leaf tissue of Brassica spp. on the growth of F. oxysporum f.sp. cepae $72 \mathrm{~h}$ after incubation. Means by the same letter are not significantly different according to Fisher LSD test at $P=0.01$. Means represent the average combined values for two experiments.

Combined data from the repeated experiments were subjected to analysis of variance and mean separation was accomplished by Fisher LSD test. All analyses were conducted using the Statistical Analysis Systems version 9 (SAS Institute, Cary, NC).

\section{Results}

In vitro test among treatments exhibited highly significant differences $(P=0.01)$ in the inhibition of the growth of Foc. The effect of macerated leaf tissue of Ethiopian mustard was the greatest inhibition followed by rapeseed, while the lowest inhibition was recorded from control (Figure 1). In in vitro test the growth of Foc size on macerated leaf tissue of cabbage and garden cress was comparatively less than control. The highest Foc growth of diameter size ( $43 \mathrm{~mm} \emptyset$ after $72 \mathrm{hr}$ ) was observed from control, while the lowest Foc size $(10 \mathrm{~mm} ø)$ with effective inhibitor properties was indicated by Ethiopian mustard crop.

In the green manure pot experiment, there was no statistically significant different effect among treatments in plant emergence (Table 1). Pot planted without infested soil (without Foc pathogen) resulted in 100\% germination of seedlings. However Brassica spp. green manure amended soil treatments slightly decreased the percent of emergency of seedling compared to control.
Fusarium basal rot disease incidence was significantly $(P<0.05)$ reduced by application of green manure amendments. A comparison of the different treatments showed that rapeseed and Ethiopian mustard treatments resulted in a significantly lower incidence of FBR than the control treatment. Rapeseed and Ethiopian mustard treatments showed high reduction of FBR incidence by $21 \%$ and $30 \%$, respectively (Table 1). Among green manure treatments Ethiopian mustard significantly reduced FBR incidence when compared to cabbage and garden cress treatments.

The efficacy of rapeseed and Ethiopian mustard treatments (relative to the control) was not varied from incidence to severity, whereas the efficacy of rapeseed and Ethiopian mustard treatments remained fairly stable. Treatments had a significant effect on mean disease severity $(P<0.05)$. A comparison of the treatments showed that Ethiopian mustard treatment resulted in a significantly lower disease severity than the control and Garden cress treatments.

The green manure amendments of rapeseed and Ethiopian mustard were significantly reduced severity by $23 \%$ and $29 \%$, respectively, compared to control treatments. Among treatments the experiment indicated that Ethiopian mustard and rapeseed plants highly reduced cull bulbs by $23 \%$ and $35 \%$, respectively, compared to control. A comparison of five treatments showed that cull bulbs were significantly $(P<0.05)$ higher for the control than for the rapeseed and Ethiopian mustard treatments, but similar for the control and garden cress treatments, with the cabbage treatment also not differing significantly from control.

Plant height was significantly $(P<0.05)$ taller in Ethiopian mustard $(36 \mathrm{~cm})$ and rapeseed $(36 \mathrm{~cm})$ amended pots compared with cabbage $(32 \mathrm{~cm})$ treated ones (Table 1 ), but not significantly different from the control. Shallot plants grown in soil amended with Brassica green manure were more vigorous in their stand than plants grown in pots without green manure amendments of infested soil pots. Green manure treatments showed significant effect $(P<0.05)$ on shallot bulb weight. The bulb weight was significantly increased from Ethiopian mustard and rapeseed green manure treated soil pots compared to control. However cabbage and garden cress weight bulbs were not significantly different from control. There was no much difference among Brassica spp. treatments on bulb weights, which were ranging from 115 to $147 \mathrm{~g} /$ pot. 


\section{Discussion}

Plants of the Brassicaceae family are well known for their ability to accumulate GSLs that, in the presence of myrosinase enzyme, release substances with antifungal activity [14]. Volatile compounds released from leaf materials from several different Brassica crops inhibited growth of pathogen Foc in in vitro tests. The laboratory experiment showed that glucosinolates and their breakdown products which are excreted from Ethiopian mustard have a high significant inhibition of Foc pathogen growth in in vitro condition. Ethiopian mustard was by far the most effective one in inhibiting fungal growth in in vitro tests. Mustard is known for containing very high levels of glucosinolates, higher than most other Brassica spp, and also produces some of the most biologically active forms of isothiocyanates [12]. All Brassica crops inhibited fungal growth of all pathogens to some degree [19]. Our finding is in agreement with others where appreciable inhibition of $F$. oxysporum growth was reported on B. napus and B. carinata [14].

The emergency of shallot seedlings from Brassica spp. green manure amendments was not significantly different. Volatile substances from chopped Brassica spp. leaves, organic wastes, and composted materials often contain substances such as organic acids that have detrimental effect on germination and plant growth $[23,24]$. A longer time interval between the incorporation of the residue and planting may reduce the phytotoxic effects without adversely affecting the control of the disease [25]; therefore sufficient time interval between incorporation of Brassica crops and planting date of shallot crop should be required.

The level of FBR disease control by Brassica spp. was found to be inconsistent between Brassica spp. All Brassica crop treatments decreased disease incidence from $7 \%$ to $30 \%$ compared with control, but Ethiopian mustard and rapeseed green manures showed the most significant biocidal effect on F. oxysporum f.sp. cepae pathogen, relative to control. Ethiopian mustard and rapeseed Brassica plants reduced FBR disease incidence by 21 to $30 \%$; however, the mean efficacy of mustard crushed and incorporation in soil treatment for decreasing disease incidence over years was $44.6 \%$ with respect to the control treatment $[19,26]$. It seems to be difficult to obtain control of F. oxysporum f.sp. cepae pathogen as effective as that achieved through fungicide applications [27]. The larger amount of Brassica plant material produces high concentration of sulphur-substituted aliphatic or allylGLSs that may have the potential to increase the efficacy of biofumigation for pathogen inhibition where Fusarium spp. are the target pathogens $[19,28]$. A few researchers also indicated that to obtain better disease control the largest amount of isothiocyanates (ITC) should be applied [29]. Application of Brassica crops as a form of pellets had been considerable reduction on survival of propagules with less than 3\% of F.oxysporum population [14]. In this regard to achieve the highest efficacy of FBR disease control, higher rates of amendment, longer decomposition period, and appropriate application method should be applied.

In terms of bulb yield, green manure amended soil increased by 10 to $42 \mathrm{~g} /$ pot yield compared with the control.
In this study among green manure amendment treatments higher bulb weights were obtained from Ethiopian mustard and rapeseed Brassica crops (145 g and $147 \mathrm{~g} / \mathrm{pot}$, resp.), which was significantly different from control. Green manure amendment of Brassica crops into soil might have provided some agronomic benefits [30].

The reduction of FBR disease severity was significantly noted in green manure amendments of Ethiopian mustard and rapeseed Brassica spp. compared to control treatment in green house experiment conditions. Ethiopian mustard and rapeseed consistently and effectively reduced FBR disease severity as well as cull bulb of shallot bulb. Results from these studies showed that Brassica spp. incorporated as green manures do have a moderate level of fungicidal activity. Overall, this research indicated that Ethiopian mustard and rapeseed Brassica crops have a good potential and possibility for control of shallot FBR disease. Researchers reported that mustard is known to contain very high levels of glucosinolates, higher than most of other Brassica spp. and also produces some of the most biologically active (high antimicrobial activity) forms of isothiocyanates [12, 17, 31]. Rapeseed green manure known as a biofumigant produces high levels of isothiocyanates in roots, with considerable effects on the suppression of soil-borne diseases $[6,19$, 32]. Several studies indicated that Brassica green manure plants with high plant biomass and high concentrations of biofumigants may produce advantages for crop soil-borne disease control [32].Rapeseed, which produces high levels of isothiocyanates in roots, was found to be more effective for soil-borne diseases; the studies indicated that Brassica green manure plants that produce high plant biomass and high concentrations of biofumigants may offer advantages over planted crops for soil-borne disease control [32]. To achieve the maximum benefit from utilizing Brassica spp. as a green manure for control of soil-borne pathogens a producer will need to choose Brassica spp. with a high potential of glucosinolate production $[16,33]$. These preliminary pot experiments showed that amending of the green manure of Ethiopian mustard and rapeseed was consistently and significantly showed to be different from control in three disease parameters. This indicated that the management of FBR disease through Brassica spp. could be promising.

The overall study indicated that Ethiopian mustard followed by rapeseed green manure had the most active fungal inhibition properties and effective reduction of shallot FBR disease. Not all Brassica crops effectively reduced FBR disease incidence, severity, and cull bulbs relative to control in greenhouse trials of shallot crop. However, incidence, severity, and cull bulb of FBR disease as well as plant vigorous and bulb weight were consistently and significantly reduced only with the Ethiopian mustard and rapeseed treatments. Results of our study demonstrated that the incorporation of Ethiopian mustard and rapeseed as green manure amendments into soils has a greater beneficial effect in reducing FBR disease in shallot crop production where the disease occurred severely. In summary Ethiopian mustard and rapeseed as green manure amendments could reduce FBR disease and delay disease progress but could not provide complete control 
effect and it can be used as a component of an integrated management strategy. Green manure of Brassica crops contained high levels of aromatic GSL in the roots, used for reduction of FBR soil-borne disease on shallot and Allium crops. Therefore it should be preferred as a management tool for conventional and organic farmers who are currently under pressure to find alternatives to chemical fumigation, practices, and more ecologically acceptable means of reducing soil pathogens to improve or maintain yields, which could be effective against various root pathogens without deteriorating soil environment. In conclusion, this study allowed for a broad examination of the potential effects of many Brassica spp. crops commonly grown in Ethiopia on F. oxysporum f.sp. cepae infested shallot crops. The results of this trial did show some promise; however further research is needed in field experiment in combinations of Brassica spp. with varying rates of green manure amendments into soils; longer decomposition period and improved application method should be done on FBR disease in the biofumigation management system for sustainable agricultural development.

\section{Conflict of Interests}

The authors declare that there is no conflict of interests regarding the publication of this paper.

\section{Acknowledgments}

This research was financed by the World Bank Development for Innovation Fund (WBDIF) and Haramaya University. Special thanks are due to the staff of DZARC for their cooperation in this research. Additional thanks are due to Eresi Megerssa and Biniyam Tessema for their capable technical assistance in this research.

\section{References}

[1] F. Kodama, "Studies on basal rot of onion caused by Fusarium oxysporum f. sp. cepae and its control," Report of Hokkaido Prefectural Agricultural Experiment Stations, vol. 39, pp. 1-65, 1983.

[2] M. J. Havey, "Fusarium basal plate rot," in Compendium of Onion and Garlic Diseases, H. F. Schwartz and S. K. Mohan, Eds., pp. 10-11, APS Press, St. Paul, Minn, USA, 1995.

[3] C. S. Cramer, "Breeding and genetics of Fusarium basal rot resistance in onion," Euphytica, vol. 115, no. 3, pp. 159-166, 2000.

[4] T. Tedla and H. Assefa, "A review of vegetable diseases research in Ethiopia," in Tsedeke abate Proceedings of the 1st Ethiopian Crop Protection Symposium, IAR, Addis Abeba, Ethiopia, February 1985.

[5] T. Getachew and Z. Asfaw, "Achievements in shallot and garlic research,” Research Report, no. 36, p. 43, 2000.

[6] M. Sarwar and J. A. Kirkegaard, "Biofumigation potential of brassicas II. Effect of environment and ontogeny on glucosinolate production and implications for screening," Plant and Soil, vol. 201, no. 1, pp. 91-101, 1998.

[7] J. F. Angus, P. A. Gardner, J. A. Kirkegaard, and J. M. Desmarchelier, "Biofumigation: isothiocyanates released from Brassica roots inhibit growth of the take-all fungus," Plant and Soil, vol. 162, no. 1, pp. 107-112, 1994.
[8] J. Matthiessen and J. Kirkegaard, "Biofumigation and enhanced biodegradation: opportunity and challenge in soilborne pest and disease management," Critical Reviews in Plant Sciences, vol. 25, no. 3, pp. 235-265, 2006.

[9] J. A. Kirkegaard, P. T. W. Wong, and J. M. Desmarchelier, "In vitro suppression of fungal root pathogens of cereals by Brassica tissues," Plant Pathology, vol. 45, no. 3, pp. 593-603, 1996.

[10] P. D. Brown and M. J. Morra, "Control of soil-borne plant pests using glucosinate-containing plant," Advances in Agronomy, vol. 61, pp. 167-231, 1997.

[11] C. Olivier, S. F. Vaughn, E. S. G. Mizubuti, and R. Loria, "Variation in allyl isothiocyanate production within Brassica species and correlation with fungicidal activity," Journal of Chemical Ecology, vol. 25, no. 12, pp. 2687-2701, 1999.

[12] U. Smolinska and M. Horbowicz, "Fungicidal activity of volatiles from selected cruciferous plants against resting propagules of soil-horne fungal pathogens," Journal of Phytopathology, vol. 147, no. 2, pp. 119-124, 1999.

[13] U. Smolinska, M. J. Morra, G. R. Knudsen, and R. L. James, "Isothiocyanates produced by Brassicaceae species as inhibitors of Fusarium oxysporum," Plant Disease, vol. 87, no. 4, pp. 407412, 2003.

[14] G. Debiase, C. Rotolo, M. Miazzi et al., "Biofumigant activity of Brassicaceae against soil-borne fungi," in Proceedings of the 3rd International Biofumigantion Symposium, p. 59, CISRO Discovery Centre, Canberra, Australia, July 2008.

[15] H. S. Mayton, C. Olivier, S. F. Vaughn, and R. Loria, "Correlation of fungicidal activity of Brassica species with allyl isothiocyanate production in macerated leaf tissue," Phytopathology, vol. 86, no. 3, pp. 267-271, 1996.

[16] J. A. Kirkegaard and M. Sarwar, "Biofumigation potential of brassicas: I. Variation in glucosinolate profiles of diverse fieldgrown brassicas," Plant and Soil, vol. 201, no. 1, pp. 71-89, 1998.

[17] A. Clark, Managing Cover Crops Profitably, Sustainable Agriculture Network, Beltsville, Md, USA, 3rd edition, 2007.

[18] M. L. Lacy and D. L. Robert, "Yields of onion cultivars in Midwestern organic soils infested with Fusarium oxysporum f. sp. cepae and Pyrenochaera rerresrris," Plant Disease, vol. 66, pp. 1003-1006, 1982.

[19] R. P. Larkin and T. S. Griffin, "Control of soilborne potato diseases using Brassica green manures," Crop Protection, vol. 26, no. 7, pp. 1067-1077, 2007.

[20] M. J. Zanón and C. Jordá, "Eradication of Clavibacter michiganensis subsp. michiganensis by incorporating fresh crop debris into soil: preliminary evaluations under controlled conditions," Crop Protection, vol. 27, no. 12, pp. 1511-1518, 2008.

[21] A. Sintayehu, P. K. Sakhuja, C. Fininsa, and S. Ahmed, "Management of fusarium basal rot (Fusarium oxysporum f. sp. cepae) on shallot through fungicidal bulb treatment," Crop Protection, vol. 30, no. 5, pp. 560-565, 2011.

[22] M. M. Rengwalska and P. W. Simon, "Laboratory Evaluation of pink Root and fusarium basal rot resistance in Garlic," Plant Disease, vol. 70, pp. 670-672, 1986.

[23] W. Oleszek, "Allelopathic effects of volatiles from some Cruciferae species on lettuce, barnyard grass and wheat growth," Plant and Soil, vol. 102, no. 2, pp. 271-273, 1987.

[24] A. A. Keeling, I. K. Paton, and J. A. J. Mullett, "Germination and growth of plants in media containing unstable refuse-derived compost," Soil Biology and Biochemistry, vol. 26, no. 6, pp. 767$772,1994$. 
[25] E. Coventry, R. Noble, A. Mead, and J. M. Whipps, "Suppression of Allium white rot (Sclerotium cepivorum) in different soils using vegetable wastes," European Journal of Plant Pathology, vol. 111, no. 2, pp. 101-112, 2005.

[26] S. M. C. Njoroge, M. B. Riley, and A. P. Keinath, "Effect of incorporation of Brassica spp. residues on population densities of soilborne microorganisms and on damping-off and fusarium wilt of watermelon," Plant Disease, vol. 92, no. 2, pp. 287-294, 2008.

[27] F. Kodama, I. Saito, and M. Takakuma, "The occurrence of Fusarium basal rot of onion and its control by benomyl," Annals of the Phytopathological Society of Japan, vol. 42, pp. 489-490, 1976.

[28] L. Lazzeri, O. Leoni, and L. M. Manici, "Biocidal plant dried pellets for biofumigation," Industrial Crops and Products, vol. 20, no. 1, pp. 59-65, 2004.

[29] M. Mari, O. Leoni, R. Bernardi, F. Neri, and S. Palmieri, "Control of brown rot on stonefruit by synthetic and glucosinolatederived isothiocyanates," Postharvest Biology and Technology, vol. 47, no. 1, pp. 61-67, 2008.

[30] J. Kirkegaard, O. Christen, J. Krupinsky, and D. Layzell, "Break crop benefits in temperate wheat production," Field Crops Research, vol. 107, no. 3, pp. 185-195, 2008.

[31] G. Chen, A. Clark, A. Kremen, Y. Lowley, and A. Price, "Brassicas and Mustards," in Managing Cover Crops Profitably, A. Clark, Ed., pp. 81-89, Sustainable Agriculture Network, Beltsville, Md, USA, 3rd edition, 2007.

[32] H. Pung, S. Cross, and D. Patten, "The use of biofumigants green manure crops for soil-borne disease management in Tasmania," in Proceedings of the 3rd International Biofumigation Symposium, p. 26, CISRO Discovery Centre, Canberra, Australia, July 2008.

[33] I. A. Zasada, H. Ferris, C. L. Elmore et al., "Field applications of brassicaceous amendments for control of soil-borne pest and pathogens," Plant Health Progress, 2003. 


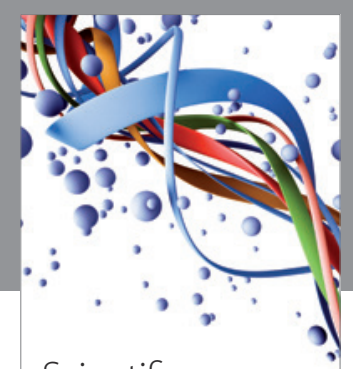

Scientifica
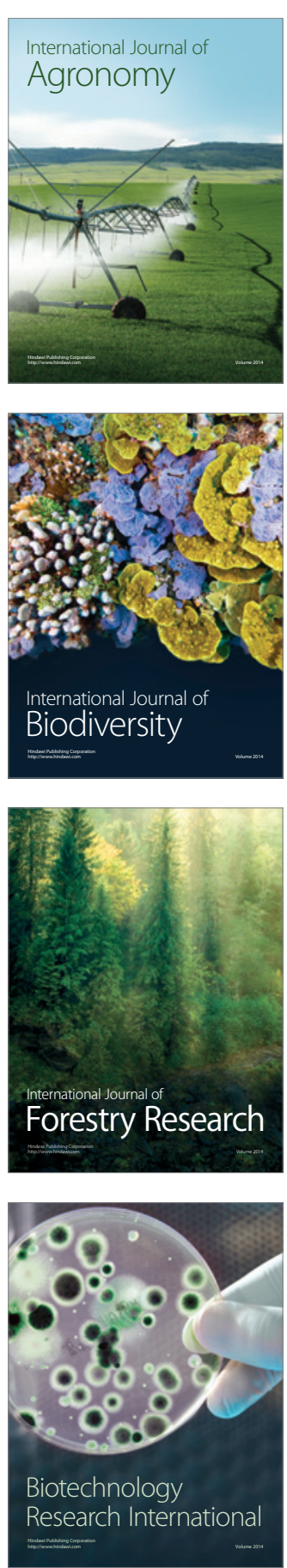
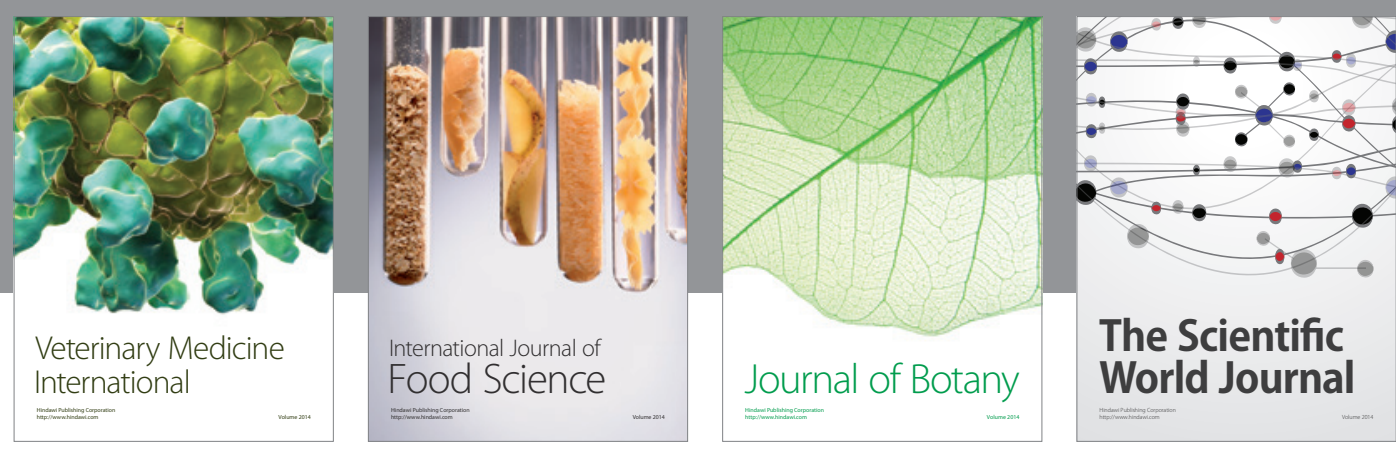

The Scientific World Journal
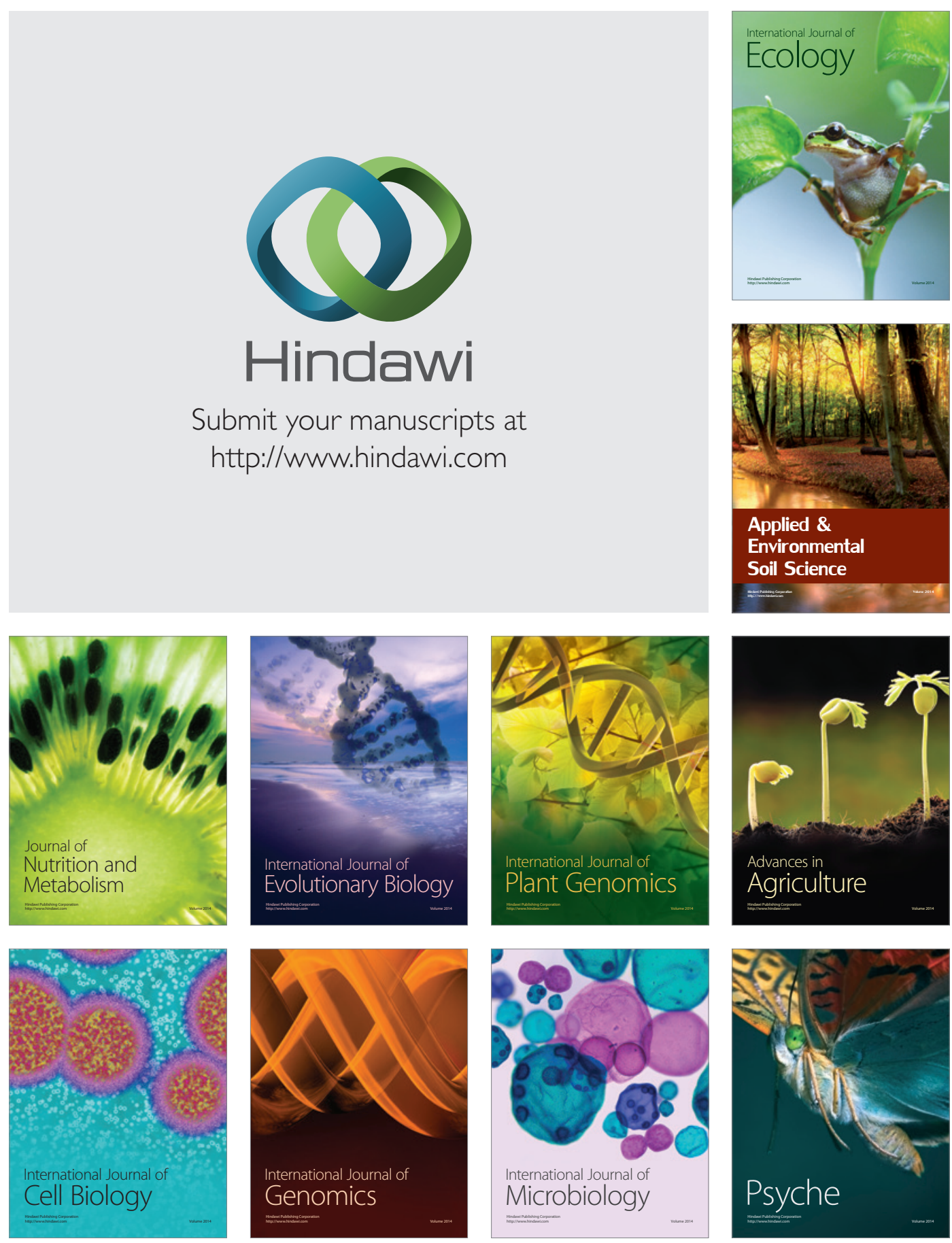